\title{
Seasonal root development of Cabernet sauvignon grafted on different rootstocks
}

\author{
Kocsis L., Baracsi Horváthné, E., Farkas Lajterné, B. \& Molnár Kocsisné, G. \\ University of Pannonia, Georgikon Faculty, Department of Horticulture, Keszthely, Hungary; \\ contact: kocsis-l@georgikon.hu
}

\begin{abstract}
Summary: The minirhizotron system gives opportunity to study the root development without disturbing the soil and root. We have found certified differences in root development during the year 2013 among the rootstocks grafted on 'Cabernet sauvignon'. The number of roots varied according to the rootstocks in different depth of soil layers and also varied the development of ripeness of the root system. We conclude that root system development is affected by soil physical and chemical properties, but differences according to the rootstock genotype on the similar type of soil exist.
\end{abstract}

Keywords: grape rootstock, vineyard, root system, minirhizotron, soil properties

\section{Introduction}

Phylloxera resistant grape rootstocks have been used widely since the end of the nineteenth century (Galet, 1988). Cultivars bred and selected to grape rootstocks originated from different Vitis species covering wide range of environmental conditions. Soil is one of the most important factors among environmental factors in viticulture (Seguin 1986, Sotes and Gomez-Miguel, 2003, Ubalde et al., 2011). Therefore grape rootstock selection is one of the key of successful vineyard management all around the world. Environmental factors strongly influence the growth rates, as a result, the role of the grape rootstocks are particularly important, especially when extreme soil conditions are given (Bertamini et al., 1992). The quantity and quality of the yield depends on both component, on grape rootstock and scion, and their combinations (Rives, 1971; Lefort és Legisle, 1977; Howell, 1987). Many efforts have been made to clarify the rootstock-scion relationship (Lefort és Legisle, 1977; Howell, 1987; Bertamini et al., 1992; Kocsis, 1998; Csikászné Krizsics, 2008), but it is very difficult to separate and measure the influence of the rootstock on the stock. The rootstock effect could be direct effect, or primary, and indirect or secondary effect on the scion (Striegler és Howell, 1991). The root system expansion and function through water and mineral uptake cause the direct effect, while growth habit, yield quantity and quality could be influenced through a carbohydrate source sink relation, or through secondary metabolites. Therefore our aim is to enhance our knowledge on seasonal root development of different grape rootstocks grafted on the top one scion, 'Cabernet sauvignon'. Knowledge can be used for better rootstock selection to similar soil conditions and for better coordination of applied phytotechnics and fertilization in the future.

\section{Material and methods}

In our study we included five rootstocks (Georgikon 28, TK 5BB, TF SO4, T5C, Fercal) grafted on 'Cabernet sauvignon' and examined the seasonal development of their roots with a minirhizotron root monitoring system. The vineyard was established in 2004 row and vine spacing is $2.9 \times 1 \mathrm{~m}$, Royat cordon trellis, 20 buds in ten 2 buds short spurs, general canopy management. A minirhizotron camera system (CID Bio-science CI-600) was set it up in 2013. Two observation tubes were placed to one stock (Figure 1) in each combination according to Taryn et al. (2008). Root system development was monitored in biweekly intervals. Total root length and surface area of the roots were measured. Meteorology data of 2013 vegetation period and soil analysis is discussed in detail.

\section{Results and discussion}

The monthly mean temperature during the vegetation period (Table 1.) was normal. The maximum temperature was extremely high in June, July and in August. The vegetation period was shorter than usual because of the minimum temperature lowest value was below 0 Celsius in the first decade of April and the last decade of October. The total amount of the precipitation was closely $400 \mathrm{~mm}$ which fits into the average. Soil was over heated during July and August at $250 \mathrm{~mm}$ depth, but it not caused any harm in root development.

The vineyard was established on brown forest soil based on dolomite stones. The Calcium content is high as it shown in Table 2, the $\mathrm{pH}$ is close to eight or above that according 
to the measurement methods. It is a clay soil, with moderate humus content. The $\mathrm{P}$ content is high in the upper layers $(0$ $600 \mathrm{~mm}$ ), what could be because of usage of manure before the vineyard establishment. The $\mathrm{K}$ and $\mathrm{Mg}$ level is in the satisfactory level.

Differences were obtained among rootstocks in the root growth. 'Teleki $5 \mathrm{C}$ ' rootstock has significantly higher proportion of root ( $244 \mathrm{~mm}$ in length), than other examined rootstocks in June 13. The date of this measurement was right in the time of blooming; therefore higher amount of newly developed roots could enhance the fertilization process. In controversial the rootstock, which has not developed many roots (Fercal $47 \mathrm{~mm}$ ), focuses mostly to fertilization process and the entire carbohydrate source directed to the flowers. Also it worth to notice that maximum temperature rose above 30 Celsius degree most of days around, therefore the transpiration rate increased. If the plants has the possibility of higher water uptake because of the number and length of the roots will develop normally.

By the end of the season most of the rootstocks have developed largest proportion of roots between 200 and $600 \mathrm{~mm}$ (Table 3 ). It is quite evident that the largest amount of root will grow where most of the mineral nutrition and organic compound can be found (Table2).

The measured total root area was also significantly different according to the rootstocks. Different rootstocks have different growing pattern in the row. While 'Teleki 5C' developed higher surface area of its root system on the West side of the grape row (Figure 2) the 'Fercal' rootstock has less differences according to the sites. The root suberization has started very early at the end of August, but there are differences according to the rootstocks in that habit too.

Our data show that differences in vineyard development could happen because of not appropriate rootstock choice to climatic and soil conditions. To have well developed, highly productive plantation (Figure 4) careful scion-rootstock combination needs to be choose.

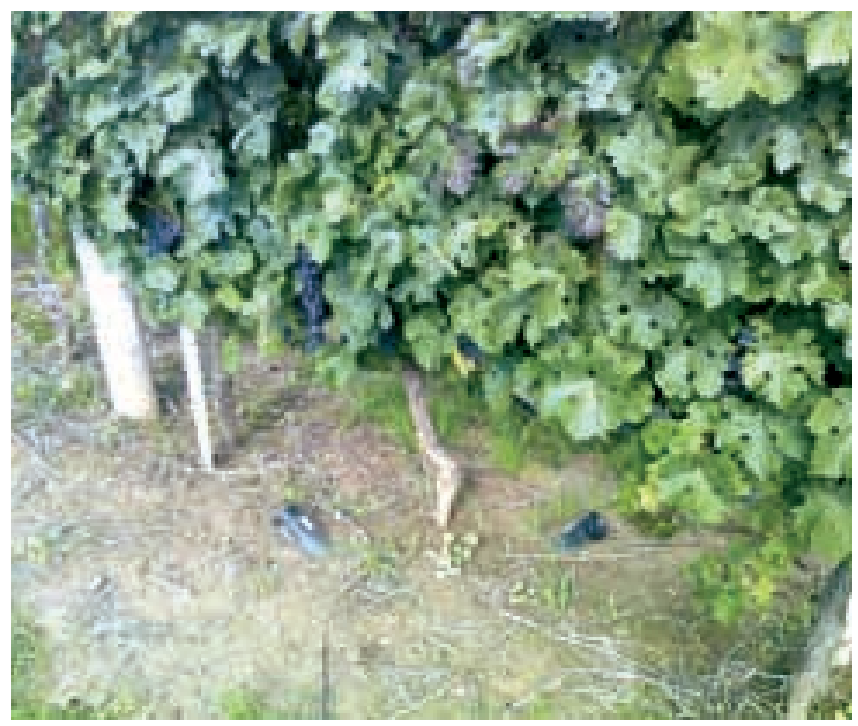

Figure 1: Installation of observation tubes in the vineyard in Cserszegtomaj
Table 1: Climatic conditions of the experimental vineyard during the vegetation period in 2013

\begin{tabular}{|c|c|c|c|c|c|}
\hline \multirow[t]{2}{*}{ Manth } & \multicolumn{3}{|c|}{ 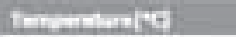 } & \multirow{2}{*}{ 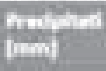 } & \multirow{2}{*}{ 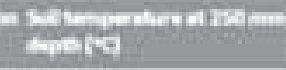 } \\
\hline & Want & Max & Win & & \\
\hline Apes & 111 & 280 & 13 & 30.6 & 63 \\
\hline Mar & 1s: & 24 & as & 728 & 102 \\
\hline Ans & 190 & 25. & 7.4 & 39.1 & 20.6 \\
\hline aly & 23 & 178 & 72 & 412 & 22.5 \\
\hline Auguat & 211 & 343 & 1.6 & 714 & 231 \\
\hline Segiamber & 247 & 275 & 15 & 768 & 164 \\
\hline Detober & 121 & 249 & 21 & 154 & 11.3 \\
\hline
\end{tabular}

Table 2: Soil analysis data of the experimentel vineyard in Cserszegtomaj, Hungary

\begin{tabular}{|c|c|c|c|c|c|c|}
\hline & ants & teras & Elines & atrats & tarkes & $\begin{array}{l}\text { andabs } \\
\text { it }\end{array}$ \\
\hline Ht|kc & 8,46 & 8.06 & 8,69 & 8,4 & 8,32 & 8,31 \\
\hline newer & $7,7 \mathbf{n}$ & 7,73 & 7,65 & $7, \mathbb{R}$ & 7,74 & 7,23 \\
\hline Sollente: & 46,89 & 46,00 & 48 & 44 & 45 & 56,60 \\
\hline $\begin{array}{l}\text { Tetainaci } \\
|=| m|m|\end{array}$ & 0,03 & 0,02 & 0,03 & 0,02 & 0.03 & 0,04 \\
\hline $\begin{array}{l}\text { Cubsantel } \\
\text { caka } \\
\text { imimal }\end{array}$ & 10,72 & 14,31 & 12,18 & 17,52 & 8,33 & 25,63 \\
\hline $\lim _{i=1}$ & 1,95 & 2.20 & 2,59 & 1,50 & 1,95 & 1,48 \\
\hline P.OSGeNel & 752,64 & 976 & 2021 & 549 & 394 & 94,24 \\
\hline s,olme/lel & 420,50 & 326,70 & 401,50 & 301,50 & 452,10 & 274,90 \\
\hline $\begin{array}{l}\text { laconsoys } \\
{[\mathrm{me} / \mathrm{h}]}\end{array}$ & 3,07 & 3,45 & 4,23 & 0,96 & 1.18 & 1,54 \\
\hline Writent & 135,44 & 143.11 & 165.75 & 135,67 & 157,26 & 160,87 \\
\hline $\begin{array}{l}\text { sa-s } \\
\text { ind }\end{array}$ & 78,28 & 76.21 & 86,32 & 75,17 & 61,72 & 54,02 \\
\hline Salmenet & 44390,60 & 56601 & 40254 & 71032 & 32309 & 107595 \\
\hline
\end{tabular}

Table 3: Average root length of both side installed tubes of the trunk related to soil depth from $0-1000 \mathrm{~mm}$ for five rootstocks at three date in 2013

\begin{tabular}{|c|c|c|c|c|c|c|}
\hline \multirow{2}{*}{ Beriage } & \multirow{2}{*}{ cest } & \multicolumn{5}{|c|}{ 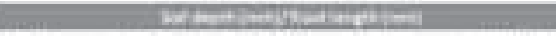 } \\
\hline & & axw & $x 00=$ & $\cos 60$ & $60=$ & En \\
\hline \multirow{3}{*}{ hater } & these & 114 & 132 & mis & as & en \\
\hline & ath & wet & jene & $\sin$ & $\cos$ & ana \\
\hline & Incenter & $w=$ & lase: & $17 \mathrm{~s}$ & wes & exta \\
\hline \multirow{3}{*}{$\begin{array}{l}\text { Whatuln } \\
\text { yod }\end{array}$} & bes & its & me & His & as & eis \\
\hline & 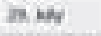 & mis & nea. & mas & ns & ing \\
\hline & motent & a. & sas & us & na & 1610 \\
\hline \multirow{3}{*}{$\begin{array}{l}\text { Mencives } \\
\text { un }\end{array}$} & tanes & tes & 123 & wis & as & 40 \\
\hline & $28 \mathrm{kr}$ & at & $m=$ & as: & tha & inet \\
\hline & 22006 & sit & $\operatorname{ma}$ & an: & inst & min \\
\hline \multirow{3}{*}{ ineplan } & tases & $\infty$ & 4 & 3. & Las & wit \\
\hline & and & 12, & ne. & xia & ans & inv \\
\hline & 12 orthen & ast & Hes: & ras & rese & $m s$ \\
\hline \multirow{3}{*}{ Inie } & $12 k$ & ass & a & $x$ & tas & en \\
\hline & m.ty & 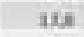 & inst & nea & $m$ & nets \\
\hline & mant & a. & ม⿻上丨 & $\operatorname{ses}$ & inse & aby \\
\hline
\end{tabular}

\section{Acknowledgement}

Our research was supported in the frame of the project „Regional effects of weather extremes resulting from climate change and potential mitigation measures in the coming decades" - TÁMOP-4.2.2.A-11/1/KONV-2012-0064. The project is realized with the support of the European Union, with the co-funding of the European Social Fund." 


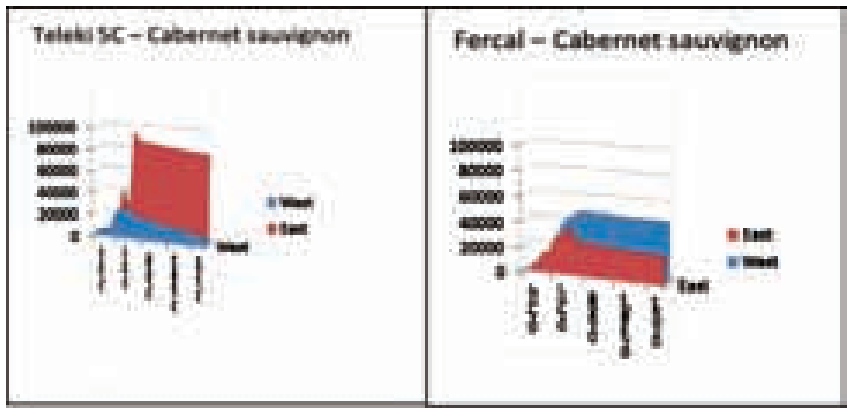

Figure 2: Total area $\left(\mathrm{mm}^{2}\right)$ of the $\mathrm{T} 5 \mathrm{C}$ and Fercal roots in $0-1000 \mathrm{~mm}$ depth of soil observed in minirizhotron tubes at east and western side of the grapevine rows

\section{Teleki 5 C rootstock root development at $600-800 \mathrm{~mm}$ soil depth (E) in 2013, Cserraegtomaj, HU}
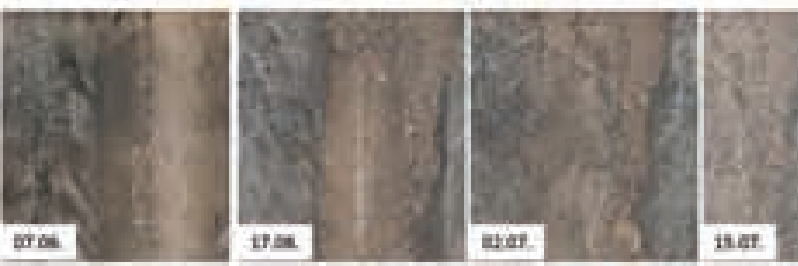

\section{TK. 568 roatstock root development at 600-800mm soil depth (E) in 2013, Csersaegtomal, HU}
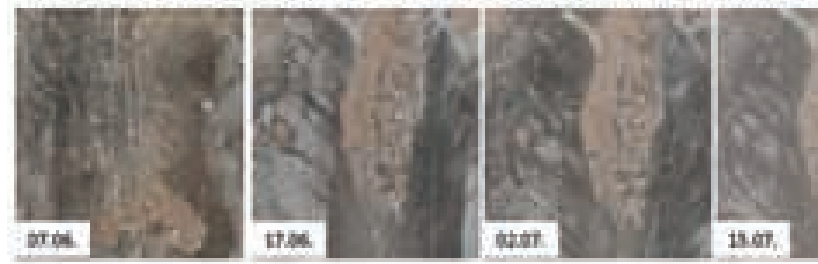

Figure 3: Root development of 'Teleki 5C' and 'Fercal' rootstocks grafted on the top Cabernet sauvignonduring the vegetation period in 2013, in Cserszegtomaj, Hungary

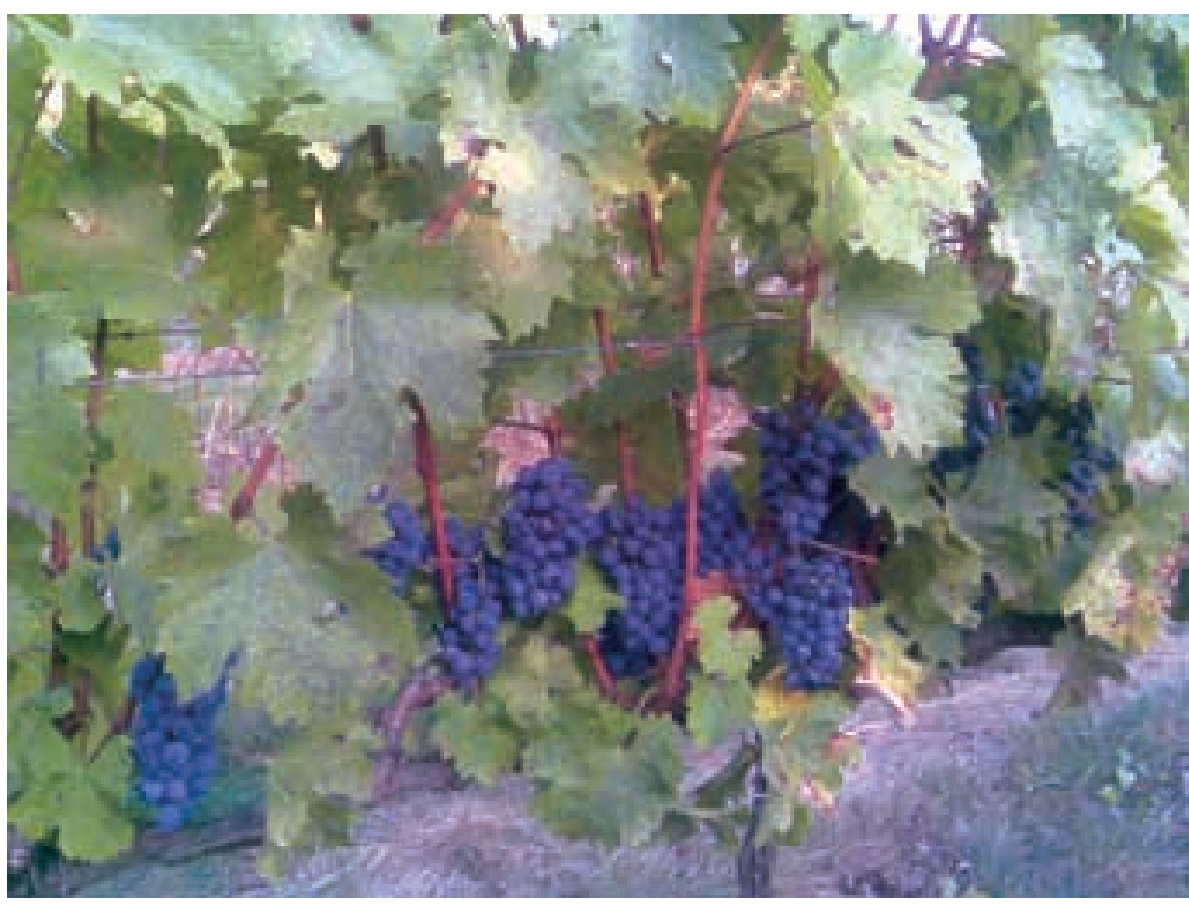

Figure 4: Cabernet sauvignon vinestock in Cserszegtomaj, Hungary
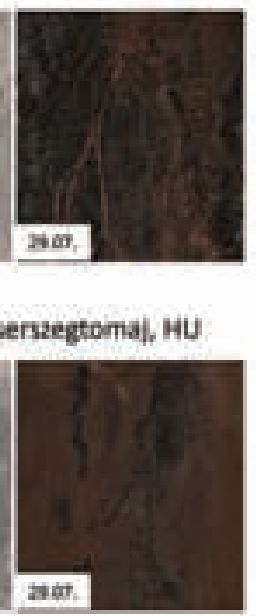

\section{References}

Bertamini, M., Falcetti, M., De Micheli, L., Stringari, G. \&

Csikászné Krizsics, A. (2008): A termésmennyiség, a termésNKTDI, Doktori értekezés.

Galet, P. (1988): Cepages et vignobles de France Tome I, Les vignes Américaines. C. Dehan, Montpellier, France.

Howell, G. S. (1987): Vitis rootstocks. [In: Rom, R. C.; Carlson, R. F. (eds.): Rootstocks for Fruit Crops.] Jhon Wiley and Sons, New York. 451-472.

Kocsis, L. (1998) Szőlő alany- és nemesfajtak kölcsönhatása az oltványkészítéstől a termőrefordulásig. Kandidátusi értekezés, MTA, Budapest.

Lefort, P. L. \& Legisle, N. (1977): Quantitative stock-scion relationships in vine. Preliminary investigations by the analysis of reciprocal graftings. Vitis. 16: 149-161.

Rives, M. (1971): Statistical analysis of rootstock experiments as providing a definition of the terms vigour and affinity in grapes. Vitis. 9: 280-290.

Seguin, G. (1986): “Terroirs" and pedology of vine growing. Experientia. 42: 861-873.

Sotes, V. \& Gomez-Miguel, V. (2003): Caracterización de areas vitivinicolas: zonificación. Memorias del I Seminario Internacional de Vitivinicultura, Ensenada, B.C. México.

Striegler, R. K. \& Howell, G. S. (1991): The influence of rootstock on the cold hardiness of Seyval grapevines. I. Primary and secondary effects of growth, canopy development, yield, fruit quality and cold hardiness. Vitis. 30: 1-10.

Bauerle, T. L., Smart, D. R., Bauerle, W. L., \& Eissenstat, D. M. (2008): Root foraging in response to heterogeneous soil moisture in two grapevines that differ in potential growth rate. New Phytologist. 179: 857-866.

Ubalde, J.M., Sort, X. \& Poch, R.M. (2011): How soil forming processes determine soilbased viticultural zoning. Journal of soil science and plant nutrition. 11:100-126. 